\title{
PENGARUH KONSELING MODIFIKASI GAYA HIDUP TERHADAP DENSITAS ENERGI MAKANAN, LINGKAR PINGGANG, DAN KADAR INTERLEUKIN-18 (IL-18) PADA REMAJA OBESITAS DENGAN SINDROM METABOLIK
}

\author{
Hafidhotun Nabawiyah, M. Sulchan*) \\ Program Studi Ilmu Gizi Fakultas Kedokteran Universitas Diponegoro \\ J1.Dr.Sutomo No.18, Semarang, Telp (024) 8453708, Email : gizifk@ undip.ac.id
}

\begin{abstract}
Background: Western-like lifestyle which consume high-fat foods isone of the cause of obesity in adolescents, particularly central obesity. Central obesity as one criteria of metabolic syndrome. Prevention of metabolic syndrome can be done through change of lifestyle into better one. One way to change the lifestyle is through counselling. The purpose of this study was to determine the effect of lifestyle modification counseling on energi density foods, waist circumference and levels of interleukin-18 in obesity adolescents.

Method: This research design was non randomized pre - post test control group design in SMAN 2 Semarang. 27 subjects were adolescents aged 16 -18 years, 16 subjects are group of not intensive counseling and 11 intensive are group of intensive counseling. Subjects were given counseling, mentoring and booklet. The data that taken were energy used FFQ, physical activity used IPAQ, waist circumference used metline, IL-18 use ELISA method. Data were analysed using Wilcoxon, paired t test, Mann Whitney, independent t test.

Results: Lifestyle modification counseling affects on diet quality $(p=0.002)$, physical activity $(p=0.001), I L-18$ $(p=0.000)$, and didn't effect on food energi density and waist circumference. The mean of diet quality intensive counseling group $7.18(0.02)$ is more significant than counterparts $7.31(p=0.04)$. Physical activity of not intensive counseling group $2335.81(p=0.00)$ high than intensive counseling $1860(p=0.18)$. The mean of energi density foods intensive counseling $1.83(p=0.21)$. The mean waist circumference intensive counseling $98.22(p=0.30)$. Levels of IL -18 (359.18)./ intensive counseling group $(p=0.00)$ more significant than counterparts.

Conclusion: There is effect of lifestyle modification counseling on physical activity, diet quality, and IL-18 and no effect on eating energi density and waist circumference. Intensive counseling group is proven to increase the diet quality and decrease IL-18, and also not proven to change the physical activity, energi density foods, and waist circumference. Unintensive counseling group affect the diet quality, physical activity, IL-18, and also not effect the energy density food and waist circumference.
\end{abstract}

Keywords: metabolik syndrome, IL-18, waist circumference, the energi density of foods

\begin{abstract}
ABSTRAK
Latar Belakang: Gaya hidup seperti negara barat dengan konsumsi makanan tinggi lemak menjadi salah satu penyebab obesitas pada remaja, khususnya obesitas sentral. Obesitas sentral, salah satu kriteria dari sindrom metabolik. Pencegahan sindrom metabolik dapat melalui perubahan gaya hidup kearah yang lebih baik. Konseling menjadi salah satu cara mengubah gaya hidup kearah yang lebih baik. Tujuan dari penelitian ini adalah mengetahui pengaruh konseling modifikasi gaya hidup terhadap densitas energi makanan, lingkar pinggang dan kadar interleukin-18 pada remaja.

Metode: Jenis penelitian non randomized pret - post test control group design di SMA Negeri 2 Semarang. 27 subjek remaja usia 16 -18 tahun, 16 subjek konseling tidak intensif dan 11 subjek konseling intensif. Subjek diberikan konseling serta pendampingan dan booklet. Data yang diambil berupa FFQ, IPAQ,lingkar pinggang dengan metline, IL-18 menggunakan ELISA. Uji statistik menggunakan Wilcoxon, paired t test, Mann whitney, independent t test.

Hasil: Konseling modifikasi gaya hidup berpengaruh terhadap kualitas diet ( $p=0.002)$, aktifitas fisik $(p=0.001)$, IL18 ( $p=0.000)$, dan tidak berpengaruh terhadap densitas energi makanan dan lingkar pinggang. Rerata kualitas diet kelompok konseling intensif 7.18 (0.02) lebih bermakna dibanding kelompok konseling tidak intensif 7.31 ( $p=0.04)$. Aktifitas fisik konseling tidak intensif 2335.81 ( $p=0.00)$ lebih bermakna dibanding konseling intensif $1806(p=0.18)$. Rerata densitas energi makanan konseling intensif 1.83 ( $p=0.21)$. Rerata lingkar pinggang konseling intensif 98.22 $(p=0.30)$. Kadar IL -18 kelompok konseling intensif 359.18( $p=0.00)$ lebih bermakna dibandingkan konseling tidak intensif.

Simpulan: Ada pengaruh konseling modifikasi gaya hidup terhadap aktifitas fisik, kualitas diet, dan IL-18 serta tidak ada pengaruh terhadap densitas energi makan dan lingkar pinggang. Kelompok konseling intensif terbukti meningkatkan kualitas diet dan menurunkan IL-18, serta tidak terbukti pada aktifitas fisik, densitas energi makanan, dan lingkar pinggang. Kelompok konseling tidak intensif berpengaruh terhadap kualitas diet, aktifitas fisik, IL-18, tetapi tidak berpengaruh terhadap densitas energi makanan dan lingkar pinggang.
\end{abstract}

Kata kunci: sindrom metabolik, IL-18, lingkar pinggang, densitas energi makanan

\footnotetext{
${ }^{*}$ Penulis Penanggungjawab
} 


\section{PENDAHULUAN}

Gaya hidup merupakan bagian dari kebutuhan sekunder manusia. Gaya hidup dapat dilihat melalui berbagai macam aspek. Gaya hidup dapat menjadi salah satu upaya untuk menjaga kesehatan dilihat dari apek pola makan dan aktifitas fisik. Gaya hidup masyarakat Indonesia saat ini cenderung mengikuti gaya hidup negara barat, tidak hanya orang dewasa, gaya hidup kearah negara barat ini juga mulai merambah pada remaja. Gaya hidup masyarakat di negara barat cenderung konsumtif, dengan pemilihan makanan siap saji. Sebagian besar makanan siap saji mengadung tinggi lemak. Selain pola makan yang tinggi lemak, gaya hidup ini juga cenderung sedikit beraktivitas berat dan lebih sering melakukan aktifitas ringan seperti menonton tv, bermain game, dan sebagainya. Pola asupan dengan tinggi lemak, serta aktivitas ringan dapat menjadi penyebab penimbunan lemak dalam tubuh. Sehingga tubuh mengalami kelebihan lemak yang disebut obesitas. ${ }^{1,2}$

Obesitas terdapat dua jenis yaitu obesitas general dan obesitas sentral. obesitas general adalah obesitas dengan penumpukan lemak di seluruh tubuh. Obesitas sentral merupakan obesitas dengan penumpukan lemak terjadi pada daerah perut dan pinggang. Obesitas sentral juga dikenal sebagai obesitas sentral atau obesitas viseral. Prevalensi obesitas sentral menurut riset kesehatan dasar tahun 2013 sebesar 26.6\%, lebih tinggi dari tahun 2007 yaitu 18,8 \%. Sedangkan obesitas pada remaja usia 16 - 18 tahun sebesar 1,6\% pada tahun 2013, lebih tinggi dari tahun 2007 $(1,4 \%)$. Obesitas sentral berhubungan dengan sindrom metabolik ${ }^{3,4,5}$. Obesitas sentral didapatkan dengan mengukur lemak viseral yang terdapat di daerah sekitar perut. Metode yang sering digunakan adalah pengukuran lingkar pinggang ${ }^{6,7}$.

Sindrom metabolik merupakan kumpulan bermacam gejala yang mempengaruhi proses metabolisme tubuh sehingga tidak bekerja dengan normal. Ada lima kriteria sindrom metabolik yaitu, obesitas sentral, tekanan darah tinggi, hipertligiserid, HDL rendah, resitensi insulin ${ }^{8}$. Kejadian sindrom metabolik sebagian besar diawali dengan adanya obesitas, khususnya obesitas abdominal. Selain itu, sindrom metabolik juga merupakan resiko terjadi penyakit kardiovaskuler dan diabetes mellitus tipe $2^{9,10}$.

Sindrom metabolik menjadi masalah sebagian besar negara maju. Akan tetapi, tahun 2000-an, sindrom metabolik tidak hanya masalah negara maju tetapi juga negara berkembang, salah satunya Indonesia. Sindrom metabolik berbanding lurus dengan kejadian obesitas sentral. Semakin tinggi obesitas maka semakin tinggi sindrom metabolik. Prevalensi obesitas di negara maju hampir sama dengan negara berkembang seperti Indonesia. Obesitas pada remaja saat ini mulai meningkat dengan beragam faktor. Beberapa faktor seperti aktivitas yang sedikit, gaya hidup yang tidak sehat.

Gaya hidup konsumtif yang cenderung ke negara barat, seperti dijelaskan di atas lebih menyukai makanan tinggi lemak dimana makanan tinggi lemak maka densitas energi makanan pun tinggi, terlalu sering dengan makanan yang memiliki densitas energi tinggi akan meningkatkan penumpukkan lemak, khususnya lemak visceral pada perut. Lemak viseral ini dapat dilihat dengan ukuran lingkar pinggang. Lingkar pinggang merupakan indikator dari sindrom metabolik.

Penelitian sindrom metabolik menggunakan biomarker pro inflamasi interleukin 18 (IL-18). IL-18 merupakan sitokin proinflamasi yang saat ini diakui sebagai indikator inflamasi yang sensitif.. Kadar IL-18 tidak hanya dapat dilihat pada orang dewasa, kadar IL-18 pun dapat dilihat pada remaja, pada penelitian sebelumnya ditunjukkan bahwa ada beda antara kelompok pra sindrom dengan sindrom metabolik. Beberapa langkah dan intervensi dilakukan untuk menangani masalah sindrom metabolik karena masalah ini merupakan masalah serius yang tidak dapat diabaikan. Beberapa intervensi berupa edukasi, konseling dan intervensi makanan ${ }^{11}$ seperti kentang, sayur - sayuran, sampai pengaturan diet seperti diet meditteranean. Diet mediterranean yang merupakan intervensi baru, dilakukan di beberapa negara dikarenakan diet meditteranean efektive dalam menurunkan sindrom metabolik. ${ }^{12,13,14,15,16}$ Bentuk intervensi pada penelitian ini lebih cenderung menggunakan metode konseling dan pendampingan untuk memodifikasi gaya hidup pada remaja.

\section{METODE}

Penelitian ini menggunakan rancang penelitian non randomized pre - post test control group design pada bulan September - November 2014. Variabel terikat dalam penelitian ini adalah densitas energi makanan, lingkar pinggang dan kadar IL-18. Variabel bebas penelitian ini adalah konseling modifikasi gaya hidup berkaitan dengan kualitas diet dan aktifitas fisik. Kelompok penelitian terbagi menjadi dua yaitu kelompok konseling intensif dan kelompok konseling tidak intensif. Pembagian kelompok ini tidak dilakukan secara sengaja, pembagian ini berlangsung secara alami seiring perjalanan konseling selama dua bulan. 
Kode etik atau ethical clearance yaitu suatu bentuk persetujuan dari Komite Etik bahwa secara etik penelitian ini boleh dilakukan pada manusia. Ethical clearance penelitian ini dikeluarkan oleh komite etik Fakultas Kedokteran Universitas Diponegoro / RSUP Dr. Kariadi Semarang. Pemeriksaan darah sampel dilakukan oleh tenaga ahli dengan dilampiri informed consent.

Subjek penelitian adalah siswa kelas XI dan XII SMA N 2 Semarang, subjek penelitian ini sama dengan subjek penelitian pendahuluan dengan random sampling. Kriteria inklusi yang digunakan adalah remaja berusia 15 - 18 tahun, mengalami obesitas yang ditandai dengan Indeks Massa Tubuh (IMT) terhadap umur dan jenis kelamin $\geq$ persentil ke-95, lingkar pinggang $\geq$ persentil ke-90, yaitu $\geq$ $93 \mathrm{~cm}$ untuk laki-laki, $\geq 87 \mathrm{~cm}$ untuk perempuan ${ }^{19}$. Kriteria eksklusi adalah subjek mengundurkan diri, sakit. Seluruh subjek penelitian 47 orang tetapi, subjek penelitian yang bersedia untuk mengikuti penelitian sampai selesai sebanyak 27 orang.

Pengukuran lingkar pinggang pada remaja dilakukan sebelum, dan sesudah intervensi. Lingkar pinggang $\geq$ persentil 90 , ukuran lingkar pinggang beresiko sindrom metabolik untuk laki - laki adalah $>93 \mathrm{~cm}$ dan perempuan $>87 \mathrm{~cm}^{19}$. Serum darah subjek penelitian dilakukan uji kadar IL-18 di Laboratorium GAKI Fakultas Kedokteran Universitas Diponegoro Semarang. Analisis kadar IL-18 dilihat dengan metode enzyme-linked immunosorbent assay (ELISA) menggunakan ELISA kit (Medical \& Biological Laboratories Co., LTD., Nagoya, Japan) menggunakan analisis dengan Dynex MRX II microplate-reader (DYNEX Technologies, Inc., Chantilly, VA USA) yang dibaca pada panjang gelombang $450 \mathrm{~nm}$ untuk mendeteksi IL-18 bioaktif. Kadar IL-18 adalah suatu biomarker proinflamasi. Kadar IL-18 dinyatakan normal jika $36-257.8 \mathrm{pg} / \mathrm{mL}$.

Densitas energi makanan adalah jumlah energi dalam berat tertentu pada makanan yang didapatkan dengan membagi asupan energi total sehari dengan berat makanan total sehari yang diperoleh dengan wawancara menggunakan FFQ semi kuantitatif ${ }^{21}$. Densitas energi makanan dikatakan normal jika 1,53--2,08 kkal/g untuk laki - laki dan 1,45 - 1,98 kkal/g untuk perempuan.

Data yang diambil berupa food frequency questionnaire (FFQ) untuk mengetahui asupan, international physical activity questionare (IPAQ), serta antropometri. Subjek penelitian diberikan konseling secara keseluruhan untuk pertemuan pertama dan pembagian booklet selanjutnya pendampingan dengan target delapan kali pertemuan dengan topic cara memaknai hasil laboratorium, obesitas dan hubungan sindrom metabolik, pengelolaan berat badan, pola makan seimbang, cara membaca label makanan, pemilihan makanan di luar rumah, gaya hidup sedenter, dan peningkatan aktifitas fisik. Pendampingan dilaksanakan seminggu sekali.

Modifikasi gaya hidup berkaitan dengan kualitas diet dan aktifitas fisik, dimana kualitas diet menggunakan diet quality index (DQI). Komponen DQI dimodifikasi dan melibatkan lima hal yaitu asupan natrium, asupan serat, densitas energi makanan, asupan lemak, dan trigliserida. Masing masing komponen memiliki nilai normal, dimana data pada rentang normal diberikan skor 2, sedangkan diatas atau dibawah rentang normal diberikan skor 1. Sehingga kualitas diet dalam penelitian ini disampaikan dengan bentuk skoring bukan deskripsi. Angka skor memiliki rentang 5 10, semakin tinggi skornya semakin bagus.

Data yang didapatkan di uji normalitas dengan Shapiro Wilk. Uji beda dua variabel menggunakan Wilcoxon untuk data berdistribusi tidak normal, dan paired $t$ test untuk data berdistribusi normal. Uji beda dua variabel pre-post menggunakan Mann whitney untuk data berdistribusi tidak normal dan independent $t$ tets untuk data berdistribusi normal. Rerata sampel untuk data pre dan post menggunakan compare mean.

\section{HASIL PENELITIAN \\ Karakteristik Subjek}

Penelitian sebelumnya menyatakan prevalensi sindrom metabolik di SMA 2 sebesar $15,2 \%$. Analisis data menunjukkan bahwa kualitas diet mengalami peningkatan dari rerata kualitas diet awal (6.33) menjadi 7.26 pada kualitas diet post dan hasil statistik menunjukkan bermakna. Densitas energi makanan pre memiliki rata-rata 1.50 relatif tetap dengan densitas energi makanan post (1.59) dan tidak signifikan. Aktifitas fisik rata - rata 1401.3 pada data awal dan mengalami peningkatan secara bermakna menjadi 2120 pada aktifitas akhir. Lingkar pinggang relatif tetap untuk data pre dan data post dan tidak signifikan. IL-18 mengalami penurunan dari rerata 405.53 menjadi 209.03 dan dikatakan bermakna oleh statistik. 
Tabel 1.Karakteristik umum

\begin{tabular}{lccc}
\hline \multicolumn{1}{c}{ Variabel } & $\begin{array}{c}\text { Total } \\
(\mathbf{n = 2 7})\end{array}$ & $\begin{array}{c}\text { Konseling Tidak } \\
\text { Intensif }(\mathbf{n = 1 6})\end{array}$ & $\begin{array}{c}\text { Konseling Intensif } \\
(\mathbf{n = 1 1})\end{array}$ \\
\hline $\begin{array}{l}\text { Umur } \\
\text { Jenis kelamin }\end{array}$ & $\mathbf{1 7}(\mathbf{1 6 - 1 8})$ & $\mathbf{1 7}(\mathbf{1 6}-\mathbf{1 8})$ & $\mathbf{1 6}(\mathbf{1 6 - 1 8})$ \\
Laki-laki & 20 & $14(87.5 \%)$ & $6(54.5 \%)$ \\
Perempuan & 7 & $2(12.5 \%)$ & $5(45.5 \%)$ \\
\hline
\end{tabular}

Tabel 1 menunjukkan karakteristik umum penelitian ini yang terdiri dari umur dan jenis kelamin. Subjek penelitian seluruhnya berjumlah 27 dengan rincian laki-laki 20 orang dan perempuan 7 orang. Rentang usia $16-18$ tahun. Kelompok konseling intensif terdapat 11 orang, dengan komposisi laki-laki 5 orang (45.5\%) dan perempuan 6 orang (54.5\%), sedangkan kelompok tidak intensif terdiri dari 14 remaja laki - laki $(87.5 \%)$ dan 2 remaja perempuan (12.5\%). Jumlah subjek penelitian pada konseling tidak intensif (16) lebih banyak dibandingkan dengan jumlah subjek penelitian pada kelompok konseling intensif (11). Kelompok tidak intensif memiliki komposisi remaja laki - laki lebih banyak dibandingkan dengan kelompok intensif karena faktor-faktor yang mempengaruhi seperti kurang peduli terhadap berat badan serta tidak tertarik untuk mengurusi hal detail terkait pola makanan seperti pemilihan jenis makanan, serta pengaturan porsi makan.

Tabel 2. Intensifitas konseling

\begin{tabular}{llc}
\hline & \multicolumn{1}{c}{ Jumlah Pertemuan } & Presentase \\
\hline Konseling intensif & $5-8$ & $3(11,11 \%)$ \\
& $1-4$ & $8(29,62 \%)$ \\
Konseling tidak intensif & 0 & $16(59,25 \%)$ \\
& Jumlah & $27(100 \%)$ \\
\hline
\end{tabular}

Tabel 2 menunjukkan variasi intensifitas frekuensi konseling. Frekuensi konseling ini digunakan sebagai dasar pembagian kelompok pada penelitian. Kelompok konseling intensif memiliki variasi konseling dari 1 - 8 kali, sedangkan konseling tidak intensif memiliki variasi frekuensi 0 . Terdapat $11,11 \%$ untuk frekuensi $5-8$, frekuensi 1 - 4 sebesar $29,62 \%$ dan 59,25\% untuk frekuensi 0 . Pembagian ini berlangsung alami seiring perjalanan waktu intervensi selama dua bulan.

Tabel 3. Penyajian rerata data pre dan post

\begin{tabular}{llll}
\hline \multicolumn{1}{c}{ Variabel } & \multicolumn{1}{c}{ Pre } & \multicolumn{1}{c}{ Post } & \multicolumn{1}{c}{ Sig $(p)$} \\
\hline Kualitas Diet & $\mathbf{6 . 3 3} \pm 1.07$ & $7.26 \pm 0.76$ & $0.002 *$ \\
Aktifitas fisik & $1401.3 \pm 1333.74$ & $2120.0 \pm 1768.07$ & $0.001 *$ \\
Densitas energi makanan & $1.50 \pm 0.31$ & $1.59 \pm 0.65$ & 0.819 \\
Lingkar pinggang & $102.90 \pm 10.82$ & $102.94 \pm 11.83$ & 0.914 \\
IL-18 & $\mathbf{4 0 5 . 5 3 \pm 1 3 2 . 5 5}$ & $\mathbf{2 0 9 . 0 3} \pm 133.54$ & $0.000 *$ \\
\hline
\end{tabular}

Tabel 3 menunjukkan data awal dan data akhir keseluruhan, terdapat perbedaan bermakna pada kualitas diet, aktifitas fisik, IL-18. Tidak ada perbedaan bermakna pada densitas energi makanan dan lingkar pinggang. Kualitas diet pre dengan rerata 6.33 meningkat menjadi 7.26 pada kualitas diet post. Perubahan rerata densitas energi makanan relatif tetap karena densitas energi makanan pre (1.50) dan post (1.59) mengalami perubahan yang kecil. Aktifitas fisik post (2120.00) lebih tinggi dari aktifitas fisik pre (1401.30). Lingkar pinggang menurut analisa statistik tidak bermakna dan rerata secara umum relatif tetap, sekalipun terdapat peningkatan dari data pre ke data post tetapi kecil. 
Tabel 4. Uji beda data awal

\begin{tabular}{|c|c|c|c|}
\hline \multirow{3}{*}{ Variabel } & \multicolumn{2}{|c|}{ Pre } & \\
\hline & \multicolumn{2}{|c|}{ Rerata \pm SD } & $\operatorname{Sig}(p)$ \\
\hline & $\begin{array}{l}\text { Konseling Tidak } \\
\text { Intensif }\end{array}$ & Konseling Intensif & \\
\hline Kualitas Diet & $6.50 \pm 1.15$ & $6.09 \pm 0.94$ & 0.34 \\
\hline Aktifitas Fisik (METs) & $1246.34 \pm 1234.96$ & $1626.60 \pm 1497.70$ & 0.49 \\
\hline Densitas Energi Makanan (kkal/g) & $1.49 \pm 0.32$ & $1.52 \pm 0.31$ & 0.83 \\
\hline Lingkar Pinggang (cm) & $106.11 \pm 11.84$ & $98.22 \pm 7.32$ & 0.06 \\
\hline IL-18 (pg/ml) & $436.56 \pm 138.46$ & $359.18 \pm 114.12$ & 0.14 \\
\hline
\end{tabular}

Tabel 4 menunjukkan tidak ada beda data pre dari kelompok intensif dan kelompok tidak intensif untuk semua varabel. Tabel 4 menunjukkan bahwa keadaan kelompok tidak intensif dan intensif berada dalam keadaan tidak beda atau kondisi kedua kelompok sama. Kondisi pre tidak ada beda diharapkan mendapatkan data post yang merupakan pengaruh dari perlakuan yaitu konseling modifikasi gaya hidup .

Tabel 5. Uji Beda Lingkar Pinggang, IL-18, Densitas Energi makanan, Kualitas Diet, Aktifitas fisik

\begin{tabular}{|c|c|c|c|c|c|c|}
\hline \multirow[t]{3}{*}{ Variabel } & \multicolumn{2}{|c|}{ Konseling Tidak Intensif } & \multicolumn{4}{|c|}{ Konseling Intensif } \\
\hline & Rer: & $\mathrm{a} \pm \mathrm{SD}$ & $\overline{\operatorname{Sig}(p)}$ & Rer & \pm SD & $\overline{\operatorname{Sig}(p)}$ \\
\hline & Pre & Post & & Pre & Post & \\
\hline Kualitas Diet & $6.50 \pm 1.15$ & $7.31 \pm 0.70$ & $0.04 *$ & $6.09 \pm 0.94$ & $7.18 \pm 0.87$ & $0.02 *$ \\
\hline $\begin{array}{l}\text { Aktifitas Fisik } \\
\text { (METs) }\end{array}$ & $1246.34 \pm 1234.96$ & $2335.81 \pm 2044.58$ & $0.00 *$ & $\begin{array}{l}1626.60 \pm \\
1497.70\end{array}$ & $\begin{array}{l}1806.00 \pm \\
1294.01\end{array}$ & 0.18 \\
\hline $\begin{array}{l}\text { Densitas Energi } \\
\text { Makanan (kkal/g) }\end{array}$ & $1.49 \pm 0.31$ & $1.42 \pm 0.28$ & 0.44 & $1.52 \pm 0.31$ & $1.83 \pm 0.94$ & 0.22 \\
\hline $\begin{array}{l}\text { Lingkar pinggang } \\
(\mathrm{cm})\end{array}$ & $106.11 \pm 11.84$ & $107.16 \pm 13.14$ & 0.42 & $98.22 \pm 7.33$ & $96.82 \pm 5.91$ & 0.30 \\
\hline IL-18 (pg/mL) & $436.56 \pm 138.46$ & $294.75 \pm 189.25$ & $0.02 *$ & $359.18 \pm 114.12$ & $183.45 \pm 93.08$ & $0.00 *$ \\
\hline
\end{tabular}

*bermakna

Tabel 5 memperlihatkan pada kelompok konseling tidak intensif terdapat perbedaan bermakna pada variabel kualitas diet, aktifitas fisik, dan kadar IL-18, dan tidak terdapat perbedaan bermakna pada variabel densitas energi makanan dan lingkar pinggang. Kualitas diet mengalami peningkatan rerata, data pre dengan rerata 6.50 menjadi 7.31 pada data post $(p=0.04)$. Rerata aktifitas fisik juga mengalami peningkatan dengan data post 2335.81 sedangkat data pre 1246.34 ( $p=$ $0.00)$. Perubahan rerata densitas energi makanan relatif tetap karena rerata data pre 1.49 mengalami penurun sedikit pada data post 1.42 . Rerata lingkar pinggang mengalami peningkatan, rerata data post 107.16 lebih tinggi dibandingkan rerata data pre 106.11 walaupun tidak bermakna. Rerata kadar IL18 data post 294.75 lebih rendah dibandingkan data pre $436.56(p=0.02)$. Kelompok konseling intensif terdapat perbedaan terhadap variabel kualitas diet, dan IL-18, serta tidak terdapat perbedaan pada aktifitas fisik, densitas energi makanan, dan lingkar pinggang. Rerata kualitas diet post (7.18) lebih tinggi dibandingkan rerata kualitas diet pre(6.09) dengan $\mathrm{p}$ value 0.02 . Aktifitas fisik mengalami peningkatan, pre (1626.60) menjadi 1806 pada post. Rerata densitas energi makanan pada data post 1.83 lebih tinggi dibandingkan data pre 1.52 . Rerata lingkar pinggang mengalami penurunan dari data pre 98.22 menjadi 96.82 pada data post walaupun tidak bermakna. Kadar IL-18 mengalami penurunan dari 359.18 pada data pre menjadi 183.45 pada data post.

Kualitas diet pada kelompok konseling tidak intensif $(p=0.04)$ dan kelompok konseling intensif ( $p=0.02)$ sama - sama bermakna, dengan angka statistik pada kelompok konseling intensif lebih kecil dibandingkan kelompok konseling tidak intensif. Aktifitas fisik kelompok konseling tidak intensif $(p=0.00)$ lebih bermakna dibandingkan kelompok konseling intensif $(p=0.18)$. Densitas energi makanan kelompok konseling tidak intensif $(p=0.44)$ dan kelompok konseling intensif $(p=0.22)$ sama-sama tidak bermakna, angka statistik kelompok konseling intensif lebih kecil dibandingkan kelompok konseling tidak intensif. Lingkar pinggang kelompok konseling tidak intensif $(p=0.42)$ dan kelompok konseling intensif $(p=0.30)$ sama-sama tidak bermakna, angka statistik kelompok konseling intensif lebih kecil dibandingkan kelompok konseling tidak intensif. Kadar IL-18 kelompok konseling tidak intensif $(p=0.02)$ dan kelompok konseling intensif $(p=0.00)$ terdapat perbedaan bermakna, dengan angka statistik konseling intensif lebih kecil dibandingkan kelompok konseling tidak intensif. 
Tabel 6. Uji beda selisih nilai pre dan post

\begin{tabular}{llll}
\hline \multicolumn{1}{c}{ Variabel } & \multicolumn{2}{c}{ Rerata \pm SD } & Sig $(p)$ \\
\cline { 2 - 3 } & \multicolumn{1}{c}{$\begin{array}{c}\text { Konseling Tidak } \\
\text { Intensif }\end{array}$} & \multicolumn{1}{c}{ Konseling Intensif } & \\
$\Delta$ Kualitas Diet & $\mathbf{- 0 . 8 1} \pm \mathbf{1 . 4 7}$ & $\mathbf{- 1 . 0 9} \pm \mathbf{1 . 0 4}$ & $\mathbf{0 . 5 9}$ \\
$\Delta$ aktifitas fisik & $\mathbf{- 1 0 8 9 \pm \mathbf { 1 3 7 3 . 6 }}$ & $\mathbf{- 1 7 9 . 4 0} \pm \mathbf{5 2 4 . 1 5}$ & $\mathbf{0 . 1 4}$ \\
$\Delta$ Densitas energi makanan & $\mathbf{0 . 0 7} \pm \mathbf{0 . 3 6}$ & $\mathbf{- 0 . 3 2} \pm \mathbf{0 . 8 1}$ & $\mathbf{0 . 1 6}$ \\
$\Delta$ Lingkar Pinggang & $\mathbf{- 1 . 0 4} \pm \mathbf{5 . 0 3}$ & $\mathbf{1 . 4} \pm \mathbf{4 . 3 0}$ & $\mathbf{0 . 2 0}$ \\
$\Delta$ Interleukin - 18 & $\mathbf{1 4 1 . 8 1} \pm \mathbf{1 8 3 . 1 1}$ & $\mathbf{1 7 5 . 7 3} \pm \mathbf{1 6 8 . 0 6}$ & $\mathbf{0 . 6 6}$ \\
\hline
\end{tabular}

Tanda negative (-) menunjukkan perubahan data yang meningkat dari pre ke post. Tidak ada tanda menunjukkan perubahan data yang menurun dari pre ke post.

Tabel 6 menunjukkan selisih rerata data pre dan post pada kedua kelompok. Selisih semua rerata secara statistik dinyatakan tidak bermakna. Tabel 6 menunjukkan perubahan rerata kualitas diet mengalami peningkatan untuk kedua kelompok dengan rincian kelompok konseling intensif mengalami peningkatan (1.09) lebih tinggi dari pada kelompok tidak intensif (0.81). Selisih rerata densitas energi makanan pada kelompok tidak intensif (0.07) mengalami penurunan sedangkan pada kelompok intensif mengalami peningkatan (0.32). Selisih rerata aktifitas fisik kedua kelompok mengalami peningkatan dengan rincian kelompok tidak intensif (1089) lebih besar dibandingkan kelompok intensif 179.40. Perubahan rerata lingkar pinggang kelompok konseling tidak intensif (1.04) menunjukkan adanya peningkatan nilai,sedangkan kelompok konseling intensif mengalami penurunan (1.4). Kadar IL-18 pada kedua kelompok mengalami penurunan. Penurunan terlihat lebih banyak pada kelompok konseling intensif (175.73) dari pada kelompok konseling tidak intensif (141.81)

\section{PEMBAHASAN}

Subjek penelitian sejumlah 27 orang, mengelompok secara alami menjadi kelompok konseling intensif yang terdiri atas 11 orang dengan komposisi remaja laki - laki $(45,5 \%)$ lebih sedikit daripada remaja putri $54,5 \%$. Hal ini terjadi karena remaja putri cenderung lebih memperhatikan berat badan serta lebih tertarik dengan penurunan berat badan dibandingkan remaja laki-laki, dan kelompok konseling tidak intensif terdiri atas 16 orang dengan komposisi remaja laki - laki $85,5 \%$ dan remaja putri $12,5 \%{ }^{20}$. Jumlah subjek penelitian kelompok konseling tidak intensif lebih banyak dibandingkan kelompok intensif, sehingga menunjukkan kecenderungan remaja yang kurang memperhatikan berat badan, adapun faktor lain seperti body image dari lingkungan sehingga dapat menurunkan percaya diri ${ }^{17}$.

Berat badan dipengaruhi oleh beberapa faktor, salah satunya adalah kualitas diet. Kualitas diet mencakup pemilihan jenis makanan sehat, pola makan seimbang dan sesuai kebutuhan. Kualitas diet memiliki rerata keseluruhan $7.26(p=0.002)$. Kualitas diet kelompok konseling tidak intensif $(p=0.04)$ lebih rendah daripada kelompok konseling intensif $(p=0.02)$. Kelompok konseling intensif memiliki tingkat kemaknaan yang lebih tinggi dibanding kelompok tidak intensif. Kondisi ini berkaitan dengan jumlah perempuan yang lebih banyak pada kelompok konseling intensif, perempuan lebih suka memperhatikan kualitas diet. Kelompok konseling tidak intensif didominasi oleh laki-laki, laki-laki tidak terlalu memikirkan diet.

Kualitas diet dilihat dari pemilihan jenis makanan berkaitan dengan tingkat densitas energi makanan. Makanan yang baik mengandung densitas energi makanan normal ${ }^{21,22}$. Densitas energi makanan merupakan jumlah total energi makanan dalam berat tertentu. Perubahan rerata densitas energi makanan relatif tetap atau mengalami sedikit perubahan. Rerata densitas energi makanan secara keseluruhan sebesar 1.59, dengan rincian kelompok konseling tidak intensif $1.42 \quad(p=0.35)$ dan kelompok konseling intensif 1.83 (0.21). Kelompok konseling tidak intensif perubahan rerata relatif tetap, sedangkan kelompok konseling intensif perubahan rerata meningkat. Akan tetapi, rerata densitas energi makanan masih dalam rentang normal $^{23,24}$

Selain kualitas diet, berat badan juga dipengaruhi oleh tingkat aktifitas fisik. Aktifitas fisik memiliki rerata keseluruhan 2120.00 dengan kelompok konseling tidak intensif (2335.81) mengalami peningkatan dan analisis statistik menyatakan bermakna. Namun pada kelompok konseling intensif (1806) juga mengalami pengingkatan tetapi tidak bermakna. Hal ini terjadi diduga karena pada kelompok konseling tidak intensif didominasi oleh remaja laki-laki. Remaja laki-laki cenderung memiliki aktifitas fisik yang tinggi seperti bermain sepakbola, futsal, dan lain sebagainya, sedangkan remaja putri cenderung memiliki aktifitas fisik dengan kategori ringan hingga sedang. 
Aktifitas fisik rendah dan kualitas diet yang kurang sesuai dapat meningkatkan penumpukan lemak, khususnya lemak pada daerah perut dan pinggang. Penumpukan lemak ini dapat menjadi obesitas sentral yang dapat dilihat dengan pengukuran lingkar pinggang. Perubahan gaya hidup dari aktifitas rendah menjadi sedang hingga tinggi, kemudian kualitas diet yang lebih baik dapat menurunkan penumpukan lemak pada perut dan pinggang. Rerata lingkar pinggang keseluruhan 102.94. Peningkatan lingkar pinggang terjadi pada kelompok konseling tidak intensif dari lingkar pinggang pre (106.11) menjadi (107.16) dengan $p=0.42$ sehingga tidak bermakna. Kelompok konseling intensif mengalami penurunan lingkar pinggang dari lingkar pinggang pre (98.22) menjadi lingkar pinggang post (96.81) tetapi analisis statistik menunjukan tidak bermakna.

Lingkar pinggang tidak mudah diturunkan karena lemak yang menumpuk tersimpan di jaringan adiposa perut sulit untuk dimetabolisme. Jaringan adiposa dapat mengeluarkan IL-18 yang menunjukkan adanya inflamasi sel dalam jaringan tersebut. Inflamasi pada sel, sama dengan kerusakan sel pada jaringan berkaitan dengan terganggunya proses metabolisme. Perubahan kualitas gaya hidup menjadi lebih baik, dapat dilihat dengan menurunnya kadar IL-18 dalam tubuh yang merupakan salah satu biomarker dari inflamasi ${ }^{25}$. Akan tetapi, penurunan IL-18 tidak hanya terjadi pada kelompok intensif, tetapi juga kelompok tidak intensif, sehingga tidak sepenuhnya bahwa penurunan kadar IL-18 hanya dipengaruhi oleh modifikasi gaya hidup dengan metode konseling. IL-18 yang merupakan salah satu biomarker proinflamasi terjadinya sindrom metabolik memeliki rentang normal $36-257.8 \mathrm{pg} / \mathrm{mL}$. Data penelitian pendahuluan menunjukkan bahwa kadar IL-18 pada subjek penilitian memiliki rerata melebihi kadar nomal, sehingga dapat diketahui bahwa sel tubuh khususnya jaringan adiposa mengalami inflamasi. Kadar IL-18 dapat diturunkan dengan modifikasi gaya hidup dengan komponen peningkatan aktifitas fisik serta keseimbangan asupan makanan. Penelitian ini memberikan modifikasi gaya hidup dengan metode konseling selama dua bulan. Data post menunjukkan kadar IL18 pada subjek penelitian mengalami penurunan yang bermakna. Analisis statistik menunjukkan tidak ada pengaruh konseling modifikasi gaya hidup dengan IL-18. Kondisi ini dapat terjadi karena terdapat beberapa faktor yang mempengaruhi seperti jumlah sampel belum memenuhi nilai minimal. Subjek penelitian sebelumnya tidak berkenan untuk mengikuti penelitian ini sehingga jumlah subjek berkurang.

Rerata nilai lingkar pinggang kelompok tidak intensif mengalami peningkatan, sedangkan rerata lingkar pinggang kelompok intensif mengalami penurunan. Sekalipun tidak ada hubungan bermakna antara lingkar pinggang sebelum dan sesudah intervensi baik pada kelompok tidak intensif maupun kelompok intensif. Lingkar pinggang mengalami penurunan lebih lama dibandingkan kadar IL-18. Akan tetapi, pada penelitian ini kadar IL-18 turun dengan diiringi tidak ada perubahan bermakna pada lingkar pinggang. Kondisi tersebut terjadi diduga karena perubahan pada sel lebih cepat terjadi dibandingkan perubahan pada antropometri, dalam hal ini lingkar pinggang.

Konseling modifikasi gaya hidup sebagai salah satu upaya memperbaiki kualitas diet dan akifitas fisik dilakukan selama dua bulan. Dua bulan diharapkan terjadi delapan kali konseling dengan hasil sesuai harapan. Selama perlakuan frekuensi konseling yang dilaksanakan bervariasi dikarenakan kesibukan dan waktu bertemu yang cukup sulit. Setiap pertemuan konselor memiliki materi atau target yang hendak disampaikan kepada subjek penelitian dengan tetap melihat kebutuhan subjek penelitian. Materi konseling lebih cenderung kepada kualitas diet dan aktifitas fisik. Konseling dilakukan di sekitar wilayah sekolah karena tempat konseling diserahkan kepada subjek penelitian untuk menentukan agar tercipta suasana yang nyaman. Konseling pertama dilakukan secara bersamaan dan dengan menghadirkan orang tua subjek. Subjek penelitian yang masih merupakan remaja tentu tidak lepas dari pengaruh orang tua.

Konseling lebih efektif dibandingkan edukasi maupun penyuluhan. Edukasi dan penyuluhan memberikan pengetahuan tapi tidak sampai mengubah perilaku. Konseling bersifat privasi, konselor dapat lebih memperhatikan kebutuhan pasiennya sehingga diharapkan dapat lebih efektif untuk mengubah perilaku menjadi lebih baik. Analisis data didapatkan bahwa tidak ada hubungan bermakna antara konseling modifikasi gaya hidup dengan lingkar pinggang, IL18, dan densitas energi makanan. Jumlah sampel yang relatif sedikit juga mempengaruhi kemaknaan data ini.

\section{SIMPULAN}

Ada pengaruh konseling modifikasi gaya hidup terhadap aktifitas fisik, kualitas diet, dan IL18 serta tidak ada pengaruh terhadap densitas energi makan dan lingkar pinggang. Kelompok konseling 
intensif terbukti meningkatkan kualitas diet dan menurunkan IL-18, serta tidak terbukti pada aktifitas fisik, densitas energi makanan, dan lingkar pinggang. Kelompok konseling tidak intensif berpengaruh terhadap kualitas diet, aktifitas fisik, IL-18, tetapi tidak berpengaruh terhadap densitas energi makanan dan lingkar pinggang.

\section{DAFTAR PUSTAKA}

1. Health N, Examina- N. Dietary Energi Density Is Associated With Obesity and the Metabolik Syndrome in U.S. Adults. 2007.

2. Vriendt T De, Moreno LA, Henauw S De. Chronic stress and obesity in adolescents: Scientific evidence and methodological issues for. Nutr Metab Cardiovasc Dis. 2009;19(7):511-519. doi:10.1016/j.numecd.2009.02.009.

3. Taverne F, Richard C, Couture P. PharmaNutrition Sentral obesity, insulin resistance, metabolik syndrome and cholesterol homeostasis. 2013;1:130-136. doi:10.1016/j.phanu.2013.07.003.

4. Tamborlane W V, Taksali SE, Yeckel CW, et al. Obesity and the Metabolik Syndrome in Children and Adolescents. 2004:2362-2374.

5. Lin C, Yu S, Wu B, Chang D. Measurement of waist circumference at different sites affects the detection of sentral obesity and metabolik syndrome among psychiatric patients. Psychiatry Res. 2012;197(3):322-326.

doi:10.1016/j.psychres.2011.09.012.

6. Janssen I, Katzmarzyk PT, Ross R. Waist circumference and not body mass index explains obesity- related health risk 1 - 3. 2004:5-7.

7. Sci BE, Article O. Visceral Fat Area, Waist Circumference and Metabolik Risk Faktors in Sentrally Obese Chinese Adults*. 2012;25(2):141148. doi:10.3967/0895-3988.2012.02.003.

8. Lee K, D M, Lee S, Kim Y, Kim Y. Waist circumference , dual-energi X-ray absortiometrically measured sentral adiposity , and computed tomographically derived intra-sentral fat area on detecting metabolik risk faktors in obese women.

2008;24:625-631. doi:10.1016/j.nut.2008.03.004.

9. Nakamura H, Ito H, Egami Y, Kaji Y. Waist circumference is the main determinant of elevated C-reactive protein in metabolik syndrome. 2008;79:330-336. doi:10.1016/j.diabres.2007.09.004.

10. Delgado-lista J, Perez-martinez P, Garcia-rios A, et al. A gene variation ( rs12691) in the CCAT / enhancer binding protein a modulates glucose metabolism in metabolik syndrome. Nutr Metab Cardiovasc Dis. 2013;23:417-423. doi:10.1016/j.numecd.2011.09.008.

11. Antonova P, Jacobs DI, Bojar M, et al. The metabolic syndrome. 2009:181-183. doi:10.1016/S0140-6736(09)61794-3.
12. The metabolic syndrome - a new worldwide definition. 2004:13-16.

13. Sargowo D, Andarini S. The Relationship Between Food Intake and Adolescent Metabolik Syndrome Pengaruh Komposisi Asupan Makan terhadap Komponen Sindrom Metabolik pada Remaja. 2011;32(1):14-23.

14. Jones JL, Fernandez ML, Mcintosh MS, et al. A Mediterranean-style low-glycemic-load diet improves variabels of metabolik syndrome in women, and addition of a phytochemical-rich medical food enhances benefits on lipoprotein metabolism. J Clin Lipidol. 2011;5(3):188-196. doi:10.1016/j.jacl.2011.03.002.

15. Akar S, Sanlier N. Compliance with Mediterranean Diet Quality Index ( KIDMED ) and nutrition knowledge levels in adolescents . A case study from Turkey $\$$. Appetite. 2011;57(1):272-277. doi:10.1016/j.appet.2011.05.307.

16. Farajian P, Risvas G, Karasouli K, et al. Very high childhood obesity prevalence and low adherence rates to the Mediterranean diet in Greek children : The GRECO study. Atherosclerosis. 2011;217(2):525-530.

doi:10.1016/j.atherosclerosis.2011.04.003.

17. Geum E, Youn S, Saeng S, et al. Effects of a 6month lifestyle modification intervention on the cardiometabolik risk faktors and health-related qualities of life in women with metabolik syndrome Metabolism. 2010;59(7):1035-1043. doi:10.1016/j.metabol.2009.10.027.

18. Bihan H, Takbou K, Cohen R, et al. Impact of shortduration lifestyle intervention in collaboration with general practitioners in patients with the metabolik syndrome. 2009;35:185-191. doi:10.1016/j.diabet.2008.11.002.

19. Mexitalia M, Agustini Utari, M Sudarno, Taro Yamauchi, Hertanto Wahyu Subagio, Agustinus Soemantri. Sindrom Metabolik pada Remaja Obesitas. M Med Indones.2009. volume 43.No.6.

20. Krisnawaty Bantas, Hari Koesnanto, Budi Mulyono. Perbedaan Gender pada Kejadian Sindrom Metabolik pada Penduduk Perkotaan di Indonesia. Jurnal Kesehatan Masyarakat Nasional, vol. 7, No.5, Desember 2012

21. Jacqueline AV, Diane CM, Barbara JR, Terryl JH. Methods for calculating dietary energi density in a nationally representative sample.Procedia Food Science 2 (2013) : 68 - 74.

22. Leila A, Ahmad E. Dietary energi density is favorably associated with dietary diversity score among female university students in Isfahan. Nutrition 282012 : 991 - 995.

23. Kentaro M, Yoshihiro M, Satoshhi S, Keiko T, Masashi A. An energi-dense diet is crosssectionally associated with an increased risk of overweight in male children, but not in female children, mal adolescents, or female adolescents in Japan : the Ryukyus Child Health Study. Nutrition Research 32 2012 : 486 - 494. 
24. Hollie AR, Shannon ML, Elizabeth ST, Marsha S, Amy AG, The Effects of an Energi Density Prescription on Diet Quality and Weight Loss : A Pilot Randomized Controlled Trial.Eat right. Journal of The Academy of Nutrition and Dietetics. September 2012. Volume 112 No.9.

25. Eric PZ, bruno Conti. Interleukin-18 null mutation increases weight and food intake and reduces energi expenditure and lipid substrate utilization in high-fat diet fed mice. Brain, Behavior, and Imuunity $372014: 45-53$. 